\title{
Freedom of Movement Needs to Be Defended as the Core of EU Citizenship
}

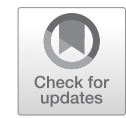

\author{
Floris De Witte
}

Freedom of movement is under attack from different sides. It is under attack politically in different Member States due to its alleged effect on the sustainability of the welfare state; it is under attack legally by the CJEU's retrenchment of the rights of the poorest of Europe's citizens; and it is under attack conceptually by those scholars and politicians who wish to understand EU citizenship to be primarily about the connection between all Member State nationals and the EU rather than focusing on the rights of mobile citizens alone. In all these accounts, the main fault line that seems to be emerging is that between mobile and immobile citizens in the EU - a fault line that the EU struggles to internalise politically and that can be traced back directly to the right to free movement.

Is there any reason to defend free movement as the core of EU citizenship? I think that there is more than one. Below, I will argue that EU citizenship should be primarily about free movement as a) it emancipates the individual from the nation state; b) it serves to recalibrate questions of justice and democracy in a more appropriate manner; and c) it lacks the ties to a homogenous political 'community of fate' that perpetuate significant exclusionary practices. For these reasons, free movement is the central thing that EU citizenship should be about: it is what makes EU citizenship distinctive from, and genuinely supplementary to, national citizenship.

\section{Free movement as emancipation}

Free movement is often understood in terms of its economic costs and benefits to the Member States of the EU. But we see something very different when we change the lens through which we look at free movement from one that is preoccupied with its effect on states to one that looks at its effect on the individual. From the latter perspective, freedom of movement is primarily about exactly that: the freedom to move out of one's own state and to choose a different type of life in a different type of place. Thus understood, free movement is an emancipatory force. It allows individuals to live their lives unencumbered by the limits that their place of birth imposes on them, 
and freedom of movement allows them to understand themselves (and the possible realisations of that self) in much more authentic terms.

This freedom of movement allows an LGBT+ couple that lives in a country in which the legal, political, cultural or social conditions do not allow for meaningful recognition of their love to move to a more permissive environment. It allows a retired teacher from Middlesbrough to enjoy her pension in sunny Lanzarote, and it allows a Romanian IT-consultant to move to Lille to live with his Hungarian girlfriend who works as a nurse in Belgium. Freedom of movement allows Europe's citizens to move for love, work, family, language, social or cultural reasons, or simply to be somewhere 'else'. It is about liberating the individual from the possibilities, opportunities, prejudices, cultural and social norms or convention (or even weather) that exists in their 'own' country, and about making available realisations of life in other states that might much more closely fit with the individual's own preferences. To turn this around, it also means limiting the capacity of states to force the individual to live her life in a particular fashion.

This emancipatory potential of free movement is not only realized through actual movement. It also has a reflexive virtue: it orients the individual's visions of self-realisation and self-understanding outwards. The possibility of free movement allows for many different realisations and understandings of the self that may have been unavailable but for free movement. Freedom of movement, in other words, liberates not only the body but also the mind from the normative structures of the state.

Free movement, as such, is to be defended normatively as it problematizes the domination that the nation state exerts over our choices, selfunderstanding and images of self-realisation. To put it as bluntly as possible, the nation state's mode of social integration reduces the incredibly complex individual to a one-dimensional being: a national. We all have many meaningful relationships and ties of identification with different groups in society, based on our profession, sexual orientation, ethnicity, religion, residence, language group, hobbies, or sharing of certain social or cultural preferences (a football team, a mode of transport, a type of music, cuisine or mode of living). The nation state, however, essentially tells us that while those relationships and patterns of identification may matter to us privately, the only one that matters for us as public individuals is that of nationality. It is with nationals, after all, that we have to share our resources and that we have to discuss what is allowed or not in society. And it is the nation-state that can coerce us into (not) taking particular actions, that can criminalise certain behaviours, that can trivialise certain needs or that can prevent certain aspirations. As Amartya Sen explains, this 'increasing tendency towards seeing 
people in terms of one dominant "identity" (...) is not only an imposition of an external and arbitrary priority, but also the denial of an important liberty of a person who can decide on their respective loyalties to different groups'. ${ }^{1}$

The first reason why freedom of movement ought to be defended as the core of EU citizenship, then, is that it enhances our capacity to understand ourselves and realise ourselves in a more authentic and genuine fashion.

\section{Free movement as a recalibration of justice and democracy}

The second reason why free movement ought to be defended as the core of the relationship between the individual and the EU is because it makes us sensitive to practices of exclusion. The construction of EU citizenship, in particularly within the context of the rights to free movement and nondiscrimination, has the potential to lead to more inclusive ways of thinking about what freedom, justice, equality and participation should mean in the EU. It also has, however, the potential to lead to more practices of exclusion. The fact that EU citizenship and free movement are not embedded in a sufficiently sophisticated, responsive and democratic institutional structure makes it very difficult for the EU to mediate the social conflict that practices of inclusion and exclusion produce, and to legitimise the choices made. ${ }^{2}$

There are many different ways to approach and address these issues. In very general terms, the right to free movement and non-discrimination attached to EU citizenship can be understood to correct instances of injustice and promote the inclusion of outsiders: it makes national distributive systems sensitive to the need to incorporate EU migrants who contribute to the host state in an economic and social way. The Court's case law, and its criteria of 'a certain degree of integration' or 'real link to the host state society' can be understood as mechanisms that serve to identify which migrants should have a right to access redistributive practices in the host state on account of the fact that they meet the conditions of reciprocity the sustain those welfare benefits.

I will not here discuss precisely how EU law attempts to balance the incorporation of outsiders in domestic practices of sharing with the need to sustain the reciprocal or solidaristic nature of those practices (which presume that access is bounded). The wider point that I am trying to make is that free movement makes us sensitive to the structural processes of

Sen, A. (2010), The Idea of Justice. London: Penguin, 247.

2 See, generally, Witte, F. (2015), Justice in the EU: The Emergence of

Transnational Solidarity. Oxford: OUP, 22-37. 
exclusion that the nation state perpetuates, and serves as an instrument to problematize these processes. Here, instead, I will touch very briefly on two of the most topical ways in which contemporary understandings of free movement and EU citizenship can be understood to produce instances of exclusion - which suggest that there is a need to defend free movement as the heart of EU citizenship.

The first example is the 'emergency brake' that the UK has managed to secure in its renegotiation on the terms of its EU membership. ${ }^{3}$ This should eventually allow for the exclusion of EU migrant workers from in-work benefits for (at most) the first four years of their presence in the UK. In the $\mathrm{UK}$, this has been presented as an exercise in justice: it ought to create more opportunities for nationals on the job market, and to prevent payments from the public purse to individuals who have not sufficiently contributed to that same public purse. This argument has been accepted by the heads of state of the other Member States and the Commission despite the absence of empirical corroboration. In fact, the most elaborate studies suggest that the fiscal effects of free movement on the UK are probably positive, and certainly neutral at worst. ${ }^{4}$ What we see here, then, is the problem if we understand freedom of movement as a luxury rather than an individual right at the heart of EU citizenship: it is prone to scapegoating and politicking, which are the exact forces that it is meant to combat. This is not to say that free movement cannot create pressures that produce exclusionary effects for national citizens (and which EU law ought to be sensitive to). It seems to me, however, first, that those pressures are primarily infrastructural (which cannot be scaled up sufficiently quick to accommodate access for all) and not of a financial nature, and second, that EU law's understanding of the limits to free movement and non-discrimination offer sufficient guarantees to prevent such practices. The compatibility of the 'emergency brake' with the right of free movement is likely to be tested if the UK votes to remain in the EU, and we could place our fate in the Court to protect free movement and nondiscrimination as being at the heart of the relationship between the individual and the EU.

Unfortunately, it appears that the Court itself is not convinced of this. The recent Dano case offers a good example of how the Court is increasingly turning its back on understanding free movement to be a right attached to the 'fundamental status' of every EU citizen. In that case, the Court

See European Council Conclusions (EUCO 1/16) 19-24, 34.

4 Dustmann, C. \& T. Frattini (2014), 'The Fiscal Effects of Immigration to the UK', Economic Journal, 124 (563): F593-F643. 
suggested that the right to basic social assistance mechanisms (as a corollary of the right to equal treatment tied to residence in a host state) is unavailable for those citizens who do not have 'sufficient resources' to take care of themselves. In a ruling that comes quite close to depicting Ms Dano in racist terms as a citizen whose presence in Germany is of no functional use to German society, the Court changes the category of EU citizens that can realistically make use of the promise of free movement. In simple terms, Dano suggests that free movement is not for all Europeans. It is not a right attached to the 'fundamental status of all EU citizens', but rather a privilege that European playboys are allowed to make use of. Again, this judgment was celebrated throughout Europe as bringing about justice; as defending the welfare systems against the parasite that is the poor (or poorly-educated) fellow European. Instead, I would argue that it is about the perpetuation of exclusion of vulnerable citizens from the processes that serve to remedy those very vulnerabilities. It is a judgment that legally mandates the creation of a European underclass of vulnerable citizens who, because of their exercise of free movement, are neither politically represented nor materially protected from the most egregious forms of exclusion. This case shows why we need to defend free movement as a right at the core of EU citizenship: something that ought to be available under similar conditions for all nationals of the Member States, and not only for the privileged ones.

\section{Free movement as separating 'the nation' from 'the state'}

The third and final reason why we ought to defend free movement at the core of EU citizenship is because of the latter's idiosyncratic structure. Unlike national forms of citizenship, EU citizenship is not linked to a 'community of fate' that reflects certain ethno-cultural ideas of a homogenous community, forged on the basis of a shared language, history, myths and ethnicity, and solidified through boundary closure, narrowly-defined membership groups and exclusion of outsiders. EU citizenship, instead, is a 'stateless' or 'anchorless' idea of belonging and community: it suggests that its subjects are part of something that is incipient, ill-defined, and diverse. Often, this is understood as the main weakness or source of illegitimacy of EU citizenship. I would argue that it is exactly its strength.

The absence of a link between the institutional idea of EU citizenship and a specified 'ethnos' or the idea of a 'nation' is exactly what makes EU citizenship normatively appealing. Accounts of the 'long history' of European integration suggest that the inter-war experience and the Second World War identified the problems with parliamentary or national sovereignty. Very simply put: democracies premised on these ideals appeared not 
to be very good at remaining democratic. On this account, the creation of the EU was deliberately meant to constrain democratic externalities, ${ }^{5}$ and particularly the capacity of states to enforce practices of internal exclusion or external aggression. In other words, EU law serves to foreclose the capacity of domestic democratic actors to commit democratic suicide. Usefully, this narrative proved appealing for Member States that acceded to the EU in the aftermath of periods of totalitarianism. This project of depoliticisation was massively helped by the role of law in the integration process. The scholarship on 'integration through law' suggests that law is both the agent and object of integration, and is used to push through the objectives of integration even in the presence of political objection on the national or supranational level.

What has all of this to do with free movement and EU citizenship, though? Free movement is at the core of the objective of constrained democracy. The legally enforceable right to enter and exit spaces of state authority and the legally enforceable right to equal consideration in whichever space an individual finds him or herself, go a long way towards limiting the power of the state to internally exclude certain groups or antagonise their neighbours. It is free movement, in a sense, which disciplines the nation state, and ensures that its civic institutional structure does not fall in the traps of the ethnos within which it historically grew. In that sense, our 'anchorless' EU citizenship is the perfect institutional container for a new - less ethnic - way of thinking about the role of the individual in the EU. ${ }^{6}$ And free movement is how this virtue is implemented. The third and final argument in defence of understanding free movement to be at the conceptual heart of EU citizenship, then, is that free movement is the perfect instrument for the implementation of the core normative promise of EU citizenship.

\section{Conclusion}

The Treaty suggests that EU citizenship is to be 'additional to' national citizenship. This contribution has argued that the added value that EU citizenship can offer primarily lies in its connection to freedom of movement. Freedom of movement, on this view, is an instrument that liberates the individual's mind and body from the domination that the nation state exerts over it; that reorients domestic processes of justice and democracy towards more

5 The most recent contribution is Muller, J.W. (2011), Contesting Democracy. Yale: Yale University Press.

6 See, generally, Azoulai, L., E. Pataut \& S. Barbou des Places (eds.) (2016), Ideas of the Person and Personhood in European Union Law. London: Hart. 
inclusive practices; and that institutionalises an idea of civic belonging on a continent that has been plagued for a century by the consequences of ethnic ideas of belonging. For these reasons, free movement must be celebrated and defended as the core of EU citizenship, as a right that is available for all 500 million EU citizens, and as an idea that benefits all those citizens whether they make use of it or not.

Open Access This chapter is licensed under the terms of the Creative Commons Attribution 4.0 International License (http://creativecommons.org/licenses/by/4.0/), which permits use, sharing, adaptation, distribution and reproduction in any medium or format, as long as you give appropriate credit to the original author(s) and the source, provide a link to the Creative Commons license and indicate if changes were made.

The images or other third party material in this chapter are included in the chapter's Creative Commons license, unless indicated otherwise in a credit line to the material. If material is not included in the chapter's Creative Commons license and your intended use is not permitted by statutory regulation or exceeds the permitted use, you will need to obtain permission directly from the copyright holder. 